\title{
Echinoid assemblages as a tool for palaeoenvironmental reconstruction - an example from the Early Miocene of Egypt
}

\author{
Andreas Kroh ${ }^{\mathrm{a}, *}$, James H. Nebelsick ${ }^{\mathrm{b}}$ \\ a Institut für Geologie und Paläontologie, Heinrichstrasse 26, 8010 Graz, Austria \\ b Institut und Museum für Geologie und Paläontologie, Sigwartstrasse 10, 72076 Tübingen, Germany
}

Received 3 October 2002; received in revised form 11 June 2003; accepted 31 July 2003

\begin{abstract}
A rich Lower Miocene echinoid fauna has been investigated from Gebel Gharra, NW of Suez, Egypt. The ca $140 \mathrm{~m}$ long section consists of a siliciclastic lower part and a carbonate-dominated upper part. This corresponds to a general transgression/regression cycle. In all, 27 different echinoid taxa were recognised. The level of taxonomic identification varies depending on test completeness and preservation of specific morphological characters. The palaeoecology of the echinoids was inferred using a functional morphological approach and actualistic comparisons. A wide variety of ecological habitats are represented with the presence of regular as well as irregular sea urchins; epibenthic as well as endobenthic forms, as well as a wide range of interpreted burrowing depths for different irregular echinoids. Seven different echinoid assemblages were distinguished, which differ with respect to the species diversity, skeletal taphonomy and sedimentary environment: (1) the Parascutella Assemblage displays spectacular mass accumulations of sand dollars accumulated by proximal storm deposits and winnowing; (2) the Cidaroid-Echinacea Assemblage represents a slightly deeper, moderate-energy environment with a highly structured habitat and corresponding variety of regular and irregular sea urchins; (3) a Spatangoid Assemblage with a diverse fauna of burrowing echinoids; (4) the Transported Assemblage represents an allochthonous collection of echinoids from shallow-water, coarse sandy substrates; (5) the Mixed Assemblage representing a slightly shallower, low- to moderateenergy environment with reduced sedimentation rates; (6) a Clypeaster martini Assemblage characterising a shallow, higher-energy environment; (7) finally, the poorly diverse Phyllacanthus Assemblage from shallow-water carbonates. Diversity variations within the assemblages are correlated primarily to substrate variation, burrowing depths as well as taphonomic factors. The transgression/regression cycle is well reflected by the echinoid assemblages, which show a general deepening of depositional environment followed by shallowing upward tendencies.
\end{abstract}

(C) 2003 Elsevier B.V. All rights reserved.

Keywords: echinoids; assemblages; palaeoecology; palaeoenvironment; Burdigalian; Egypt

\section{Introduction}

\subsection{Functional morphology of echinoid skeletons}

* Corresponding author.

E-mail address: discometra@gmx.at (A. Kroh).

Echinoids cover a wide range of environments in and on the sediment. They include generalist as 
well as specialist, both epi- and endofaunal forms, and employ different feeding mechanisms which exploit different food resources. Echinoids are common members of the benthic fauna in a wide range of habitats, in some cases even dominating the benthic community. Although some are inherently unstable and fall apart after death and may not be present as complete tests (e.g. most regular echinoids, Kier, 1977), careful collection of spines and larger fragments allow many 'missing' faunal elements to be considered (Nebelsick, 1992a).

There is an immense potential in the use of functional morphology of echinoids for palaeoenvironmental analysis (Smith, 1978, 1980a,b,c, 1984; Kanazawa, 1992; Néraudeau, 1995; Carter, 1997). The detailed study of skeletal characters can provide information concerning the general life habits, substrate relationships, feeding mechanisms, burrowing depth of infauna, respiration and so on. These include among others: (1) general shell morphology; (2) position of mouth and anus; (3) spine movement and function derived from tubercle morphology; (4) tube feet morphology from ambulacral pores. Since the morphology of echinoids is very closely tied to the environment, they are excellent tools for reconstructing palaeoenvironments and it is surprising that they have not been used more widely in this respect.

An additional aid to palaeoenvironmental reconstruction is actualistic comparison to closely related extant taxa or taxa with similar test morphologies (e.g. Kier, 1964; Bell and Frey, 1969; Birkeland and Chia, 1971; Timko, 1976; Smith, 1981; Bentley and Cockcroft, 1995). This allows the direct correlation of test morphology to ambient environmental parameters. Furthermore, information as to behaviour, population densities, synecology and animal/sediment relationships can be gained. Broader-based studies have also shown changes of echinoid faunas with respect to facies relationships (e.g. Kier and Grant, 1965; Kier, 1975; Nebelsick, 1992a,b).

Applications of the functional morphological approach as well as actualistic comparisons outlined above have allowed for a number of detailed palaeoecological interpretations of fossil echinoid assemblages, pioneered by the works of Kier
(1972) and Boggild and Rose (1984) (e.g. McNamara and Philip, 1980; Dodd et al., 1985; Carter et al., 1989; Néraudeau, 1991, 1992; Néraudeau and Floquet, 1991; Smith et al., 1995; Rose and Watson, 1998; Kroh and Harzhauser, 1999; Néraudeau et al., 2001). Néraudeau et al. (2001), for example, suggested the presence of ecomorphological gradients within Miocene echinoid assemblages based on echinoid morphologies and the bathymetric distribution of extant echinoids.

\subsection{Geological setting}

The studied section lies on the flanks of the Gebel Gharra hill in the Eastern Desert, NW of Suez, Egypt (Fig. 1). The ca 140-m thick section consists of shallow marine siliciclastics overlain by shallow marine limestones (Fig. 2). Planktonic foraminifera, calcareous nannoplankton, and miogypsinids indicate a Late Burdigalian age (planktonic foraminifera zone M2-M4, nannoplankton zone NN4, and shallow benthic zone SB25; Abdelghany and Piller, 1999; Mandic and Piller, 2001). The section is probably identical to the famous fossiliferous locality of Gebel Gineifa (= Gebel Geneffe) visited by Fuchs $(1878,1883)$ and Blanckenhorn (1901).

The section represents a general transgression/ regression cycle (Piller et al., 1998; Abdelghany and Piller, 1999; Mandic and Piller, 2001). The transgression sequence is represented by siliciclastics (beds 1-15), the regression is dominated by carbonates (beds 16-42). The base of the section consists of ca $11 \mathrm{~m}$ of fluvial/fluvio-marine crossbedded sands and silts (beds 1 and 2). These are partly bioturbated with rare plant remains and are considered Oligocene in age (Said, 1990). The lowermost marine sediments are coarse sandstones (beds 3 and 4) including mass accumulations of sand dollars (see detailed investigation in Nebelsick and Kroh, 2002). The base of bed 3 is erosive and contains sandstone cobbles. The following beds are poorly exposed but contain two distinct beds consisting of echinoderm-rich sands (bed 5) and marls (bed 6). Overlying the poorly exposed part bioturbated sands (bed 7a) and a Planostegina rudstone (bed $7 \mathrm{~b}$ ) which contain mud pebbles as well as a rich invertebrate assem- 

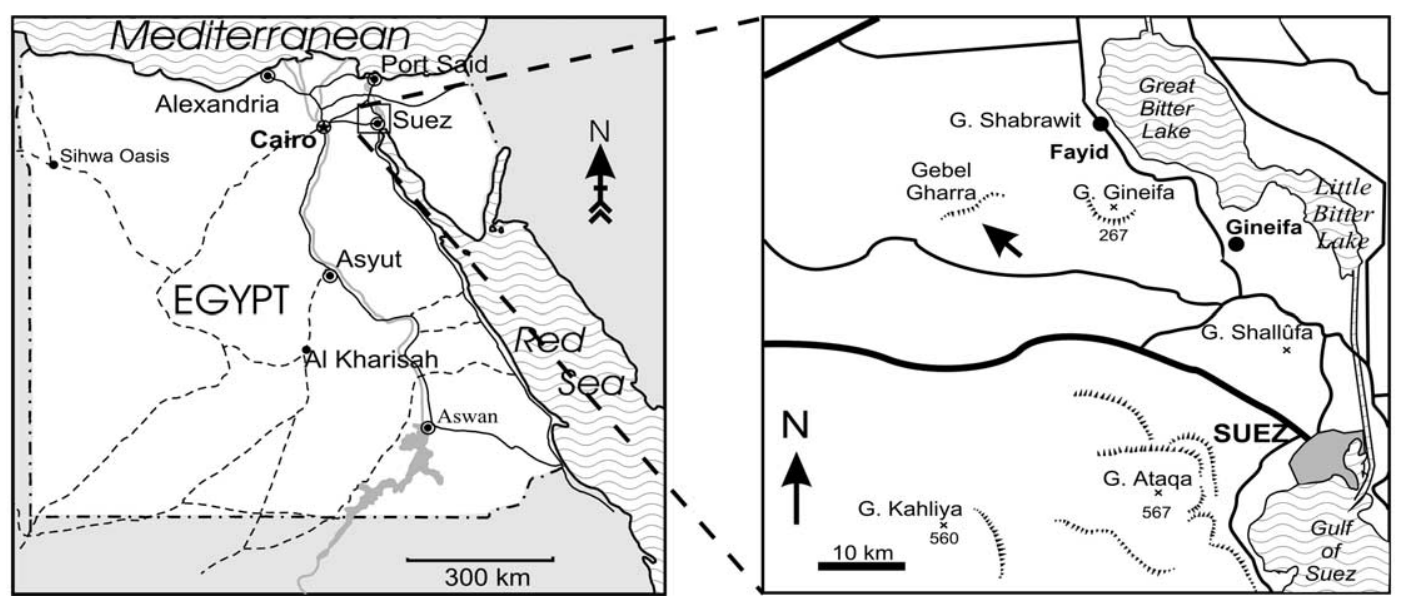

Fig. 1. Location of the Gebel Gharra section.

blage including echinoids are outcropping. This bed is followed by coarse to fine fossiliferous calcareous sandstones (beds $8 \mathrm{a}-\mathrm{f}$ ) punctuated by distinct pectinid coquinas (Mandic and Piller, 2001). The finer sediments in these beds contain a rich irregular echinoid fauna. These sediments grade into thick non-fossiliferous marls (beds $9 \mathrm{a}$ and b). These are terminated by glauconitic sandstones and limestones (beds 10-12) representing a slightly shallower, low- to moderate-energy environment, probably with reduced sedimentation. Above these beds, another succession of marls, silts and fine sands, which is terminated by coarse sand intercalations, is developed (beds 13-14). Directly on top of this succession are coarse sandstones, grading into calcareous sandstones (beds 15-16). These again contain abundant sea-urchin skeletons.

The top of the section consists of ca $40 \mathrm{~m}$ of carbonates (beds 16.1-30) with coralline algae, green algae, corals, pectinids, oysters, larger foraminifera, but few echinoid remains; $8 \mathrm{~m}$ of siliciclastics (beds 31-36) and ca $14 \mathrm{~m}$ thick carbonates (beds 37-42). This calcareous development is generally poorer in echinoids. Details of sedimentological developments can be found in Mandic and Piller (2001).

\section{Material and methods}

All echinoids have been subject to a detailed taxonomic study (Kroh, 2000, submitted). This revision also encompassed the material collected in the mid-19th century by Fuchs $(1878,1883)$. Identification to species level was attempted whenever possible. An open nomenclature was used when specimens could not be assigned to previously described species and were not sufficiently preserved to create new ones. Disarticulated or fragmented material could in many cases only be determined to family level or even higher systematic units. Quantitative analysis was possible for two beds: bed 3 was analysed using echinoid fragments within bulk samples (see Nebelsick and Kroh, 2002); in bed 8, all discovered echinoid remains, both fragmentary and complete, were identified and counted using a minimum-individual-number approach. Palaeoecological interpretations of echinoid faunas are based on the functional morphological analyses of numerous characters of the skeleton following Smith (1978, 1980a,b,c, 1984) and Kanazawa (1992), as well as actualistic comparisons to related extant taxa. A list of taxa is given in Table 1, the interpreted life habits and ecological requirements in Table 2.

\section{Results}

A total of 27 echinoid taxa were identified, mostly present as denuded coronas, in some cases only by test fragments or spines. Seven echinoid 


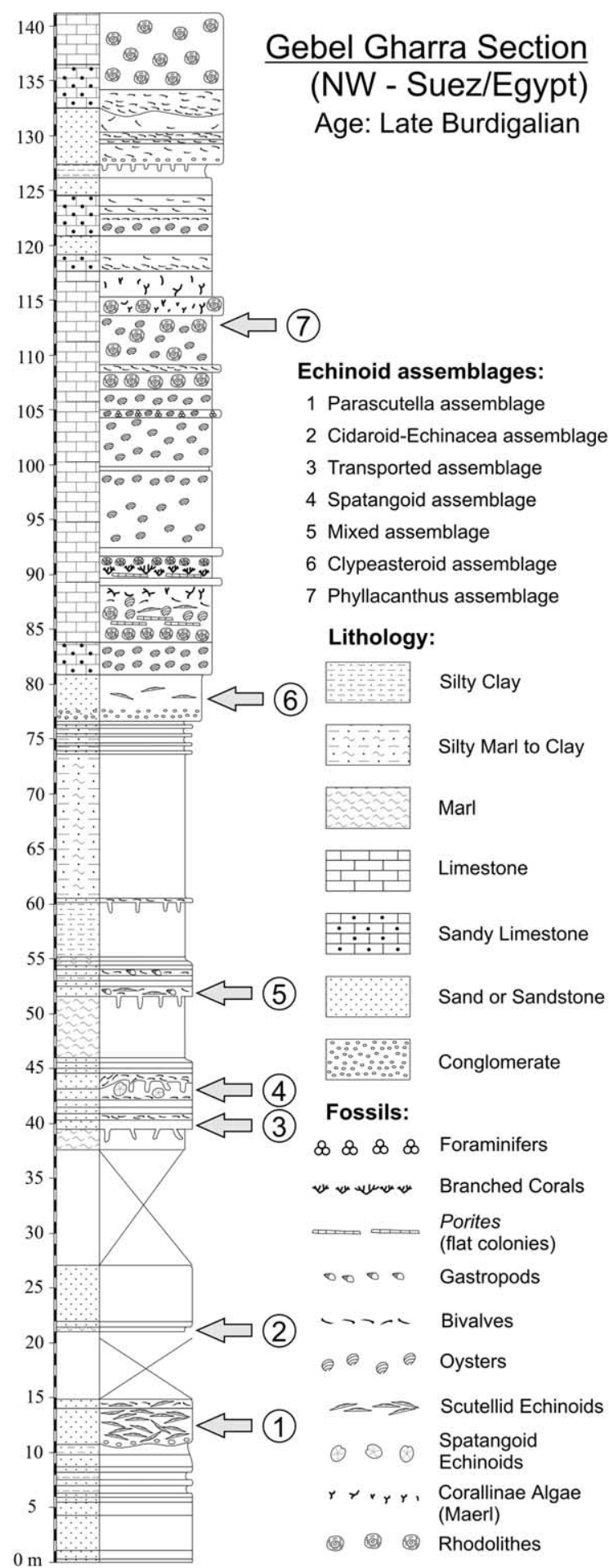

Fig. 2. Gebel Gharra section: The positions of the echinoid assemblages are marked by arrows. assemblages were recognised. These can dominate the benthic community. In other cases, they codominate or are even subordinate, but distinct enough to characterise a distinct assemblage. These echinoid assemblages are described in detail below, along with co-occurring organisms and sedimentological characteristics of the bed in which they occur.

\subsection{Parascutella Assemblage}

\subsubsection{Bed 3 - Description}

The ca $3.5-\mathrm{m}$ thick bed consists of coarsegrained, moderately sorted calcareous sandstone. It has an erosive base, which cuts deeply into the underlying fine sands and silts. Above the base, reworked sandstone cobbles, clay clasts and transported shell fragments are found. As a whole, this bed is very fossiliferous, with numerous individuals and fragments of the sand dollar Parascutella deflersi (Fig. 3a). These echinoids are conspicuously concentrated in three distinct layers, the first two of which can be traced over the whole length of the outcrop (ca $300 \mathrm{~m}$ ). These layers vary somewhat in thickness and exact position within the bed but are always present. Complete and fragmented Parascutella specimens are present in such high numbers that they build componentsupported echinoid breccias. The bases of the first two layers are undulating. The echinoids often show jamming features and imbrications. A detailed description and interpretation of the taphonomic and sedimentologic characteristics of these beds are found in Nebelsick and Kroh (2002).

Subordinate echinoids include: Amphiope bioculata, Clypeaster acclivis and Echinolampas ampla (Fig. 3b-d). Additionally, the oysters Lopha virleti, Ostrea digitalina and Anomia phippium, the pectinid Aequipecten submalvinae and moulds of venerid bivalves are occasionally present (taxonomic determination by $\mathrm{O}$. Mandic). The result of the bulk sample analysis (Fig. 4) confirms the dominance of Parascutella deflersi, as all other echinoids are relatively rare.

\subsubsection{Functional morphology and actualistic comparisons}

Parascutella deflersi has a very flat test profile, a 
Table 1

Species composition in echinoid assemblages of the Gebel Gharra Section, Eastern Desert, Egypt

\begin{tabular}{|c|c|c|c|c|c|c|c|}
\hline & $\begin{array}{l}\text { Parascutella } \\
\text { Assemblage }\end{array}$ & $\begin{array}{l}\text { Cidaroid- } \\
\text { Echinacea } \\
\text { Assemblage }\end{array}$ & $\begin{array}{l}\text { Transported } \\
\text { Assemblage }\end{array}$ & $\begin{array}{l}\text { Spatangoid } \\
\text { Assemblage }\end{array}$ & $\begin{array}{l}\text { Mixed } \\
\text { Assemblage }\end{array}$ & $\begin{array}{l}\text { Clypeaster } \\
\text { martini } \\
\text { Assemblage }\end{array}$ & $\begin{array}{l}\text { Phyllacanthus } \\
\text { Assemblage }\end{array}$ \\
\hline \multicolumn{8}{|l|}{ Cidaroida } \\
\hline Phyllacanthus sp. & & & & & & & $\mathrm{X}$ \\
\hline $\begin{array}{l}\text { Prionocidaris avenionensis (Des Moulins, } \\
\text { 1837) }\end{array}$ & & $\mathrm{X}$ & & & $\mathrm{X}$ & & \\
\hline \multicolumn{8}{|l|}{ Echinacea } \\
\hline Arbacina monilis (Desmarest, 1822) & & $\mathrm{X}$ & & & & & \\
\hline Brochopleurus fourtaui (Lambert, 1907) & & $\mathrm{X}$ & & & & & \\
\hline Brochopleurus cf. gajensis (Duncan and & & & & $(\mathrm{X})$ & $\mathrm{X}$ & & \\
\hline Sladen, 1886) & & & & & & & \\
\hline Temnopleuridae indet. & & $\mathrm{X}$ & & & & & \\
\hline Schizechinus sp. & & & $\mathrm{X}$ & & & & \\
\hline $\begin{array}{l}\text { Psammechinus dubius var. coronalis (Lam- } \\
\text { bert, 1910) }\end{array}$ & & & & & $\mathrm{X}$ & & \\
\hline Echinacea indet. & & $\mathrm{X}$ & & & & & \\
\hline \multicolumn{8}{|l|}{ Cassiduloida } \\
\hline Echinolampas ampla Fuchs, 1883 & $\mathrm{X}$ & & $\mathrm{X}$ & & & & \\
\hline Echinolampas sp. & & $\mathrm{X}$ & & & & & \\
\hline \multicolumn{8}{|l|}{ Clypeasteroida } \\
\hline Clypeaster acclivis Pomel, 1887 & $\mathrm{X}$ & & & & & & \\
\hline Clypeaster martini Des Moulins, 1837 & & & $\mathrm{X}$ & $(\mathrm{X})$ & & $\mathrm{X}$ & \\
\hline Clypeaster sp. A & & & $\mathrm{X}$ & & & & \\
\hline Clypeaster sp. B & & & & $(\mathrm{X})$ & & & \\
\hline Echinocyamus stellatus Capeder, 1907 & & $\mathrm{X}$ & & & & & \\
\hline Echinocyamus sp. & & $\mathrm{X}$ & & & & & \\
\hline Parascutella deflersi (Gauthier, 1901) & $\mathrm{X}$ & & & & & & \\
\hline Amphiope bioculata (Des Moulins, 1837) & $\mathrm{X}$ & & & & & & \\
\hline Scutellidae indet. & & $\mathrm{X}$ & & & & $\mathrm{X}$ & \\
\hline \multicolumn{8}{|l|}{ Spatangoida } \\
\hline Pericosmus latus (Desor, 1847) & & & & $\mathrm{X}$ & $\mathrm{X}$ & & \\
\hline Schizaster eurynotus Agassiz, 1841 & & & & $\mathrm{X}$ & & & \\
\hline Trachyaster? cotteaui (Wright, 1855) & & & & $\mathrm{X}$ & & & \\
\hline Brissopsis crescentica Wright, 1855 & & & & $\mathrm{X}$ & & & \\
\hline Spatangus (Platyspatus) sp. & & & & $\mathrm{X}$ & & & \\
\hline Spatangus (Phymapatagus) sp. & & & & $\mathrm{X}$ & & & \\
\hline Spatangoida indet. & & $\mathrm{X}$ & & & $\mathrm{X}$ & & \\
\hline
\end{tabular}




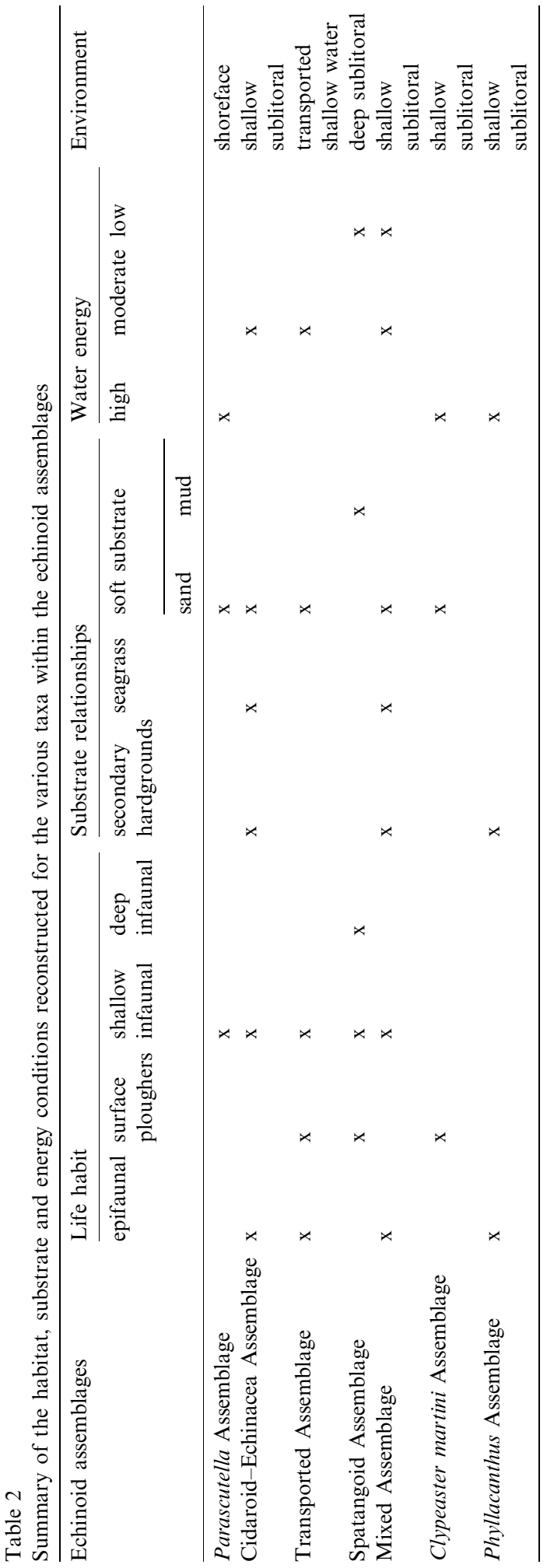

relatively thick wall and is reinforced by internal supports. Individual coronal plates are not only held tightly together by suture-spanning collagen fibres, but are also strengthened by interlocking rigid stereom projections that penetrate deeply into adjacent plates (Seilacher, 1979). This very robust coronal construction of sand dollars has been interpreted as an adaptation to higher-energy, sandy environments (Seilacher, 1979; Nebelsick, 1999). The relatively stable skeletons of these echinoids have a higher preservation potential than most other echinoids, as reflected by their extensive fossil record (Wagner, 1974; Smith, 1984; Dodd et al., 1985; McKinney, 1985; Nebelsick, 1999). Living sand dollars show a wide geographic distribution, occurring from tropical to polar latitudes (Ghiold and Hoffmann, 1984, 1986). They are generally restricted to shallowwater, high-energy, sandy environments. Both endobenthic deposit feeders (Bell and Frey, 1969; Ebert and Dexter, 1975; Bentley and Cockcroft, 1995) as well as suspension feeders (Birkeland and Chia, 1971; Timko, 1976; Smith, 1981; Beadle, 1989) occur. The deposit-feeding forms (including Mellita, Encope, Leodia or Echinodiscus) are very shallow burrowers, whereas suspension-feeding forms maintain a partially exposed vertical position in the sediment (e.g. Dendraster - Timko, 1976).

Parascutella deflersi is a deposit feeder, since it lacks the strong anteroposterior asymmetry associated with suspension feeding (Beadle, 1989). The less common Amphiope bioculata is also interpreted as a deposit-feeding sand dollar, as it shows the same general construction features as $P$. deflersi with the exception of the ambulacral lunules. The function of lunules in Recent and fossil sand dollars is debated. Various interpretations have been made, including: (1) increasing food gathering capacity, and (2) increasing hydrodynamic stability (see Smith and Ghiold, 1982 for a detailed review of lunule function). The differences in the ecological requirements of Parascutella and Amphiope are not known, but an interesting fact is that these two genera commonly occur together, with either one or the other totally dominating the echinoid fauna.

Living representatives of the genus Clypeaster 

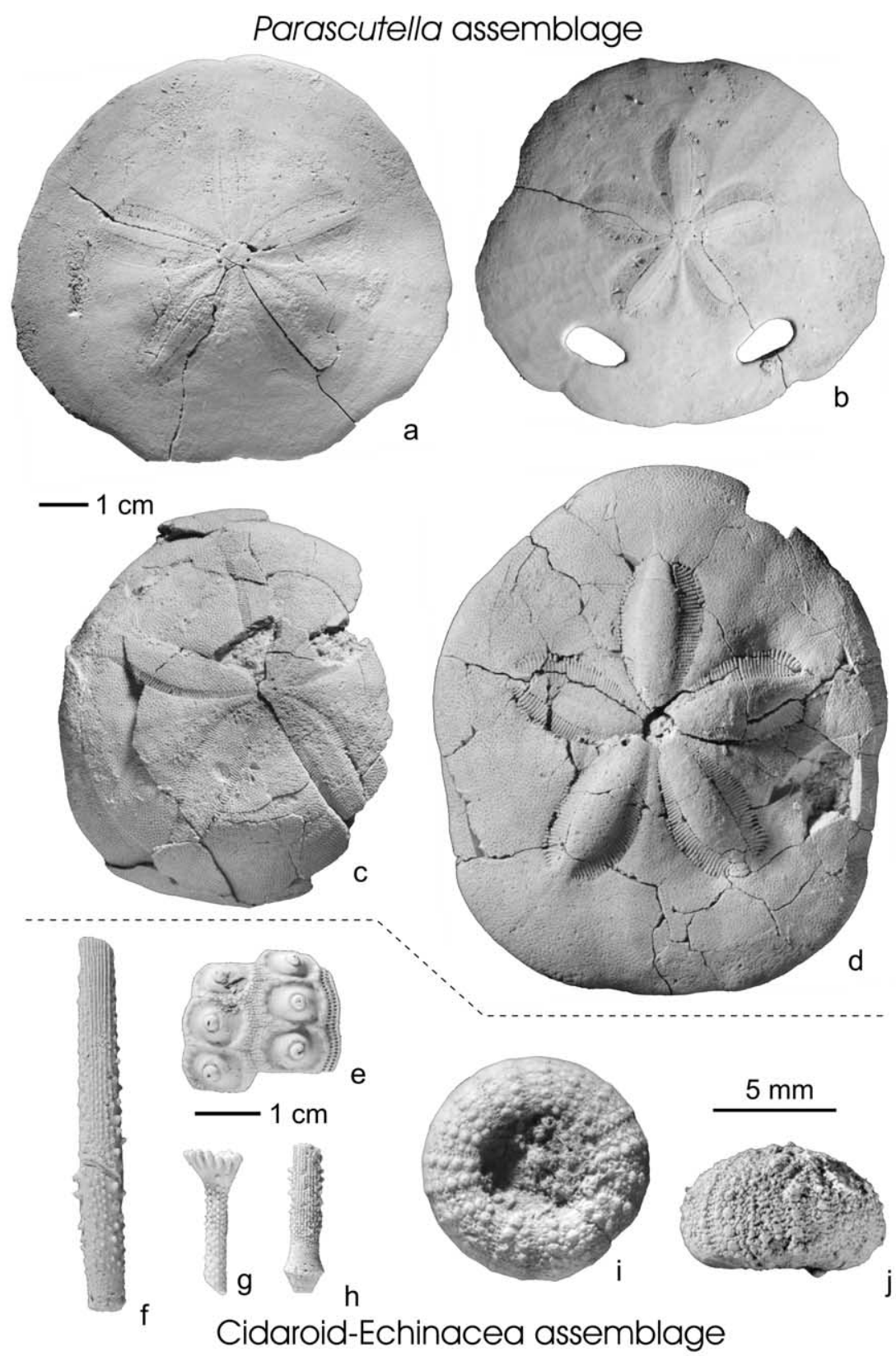

Fig. 3. Species composition of echinoid assemblages. Parascutella Assemblage: (a) Parascutella deflersi (Gauthier, 1901); (b) Amphiope bioculata (Des Moulins, 1837); (c) Echinolampas ampla Fuchs, 1883; (d) Clypeaster acclivis Pomel, 1887; Cidaroid-Echinacea Assemblage: (e-h) Prionocidaris avenionensis (Des Moulins, 1837) (e, ambital test fragment; f, spine shaft; g, spine tip; h, spine base); (i) Arbacina monilis (Desmarest, 1822); (j) Brochopleurus fourtaui (Lambert, 1907).

include shallow-burrowing and epibenthic deposit feeders. Burrowing forms such as Clypeaster subdepressus have a flat test profile and a rather thin margin, whereas epibenthic forms such as $\mathrm{Cly}$ - peaster rosaceus have a high test profile and a thick, tumid margin (Kier and Grant, 1965; Hendler et al., 1995). Clypeaster acclivis seems to represent an intermediate form between these two 


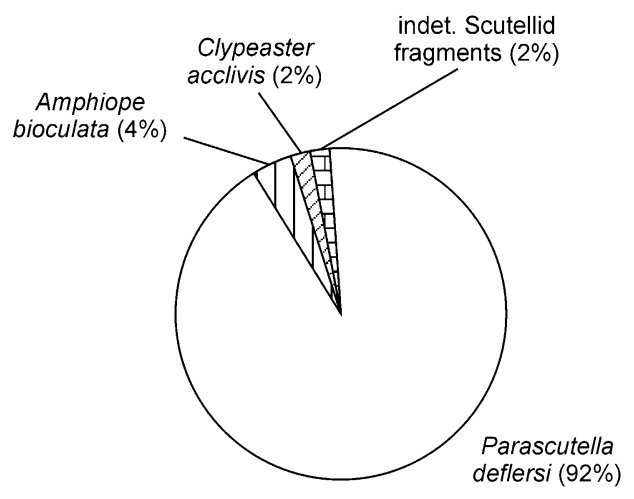

Fig. 4. Weight percentages of echinoid fragments derived from a bulk sample from bed 3 .

extremes, having a moderately thick, tumid ambitus and only a moderately high test profile. This form is therefore interpreted to have been a partially burrowed deposit feeder. Its ventral surface also is not flat, as characteristic for burrowing species of Clypeaster (Kier and Grant, 1965), but includes an infundibulum.

Echinolampas ampla is also an inhabitant of shallow sandy environments. The biology of extant representatives of the cassiduloid genus Echinolampas is poorly documented; the few reports available (Mortensen, 1948; Thum and Allen, 1975) indicate that they prefer coarse sandy substrates in shallow water depth. Palaeoecological investigations in fossil Echinolampas species by Roman (1965), Roman and Philippe (1978), McNamara and Philip (1980) and Philippe (1998) suggest that Echinolampas was a shallowwater organism, most commonly between 10 and $500 \mathrm{~m}$ water depth, where it inhabited firm, sandy bottoms and lived partially burrowed (up to the tips of its petals).

\subsubsection{Palaeoenvironmental interpretation}

The palaeoenvironment of bed 3 is interpreted as a shallow-water, shoreface, coarse sandy habitat with fully marine condition and high water energy. The shallow or partially burrowing echinoids, which were all well adapted to higher water energies, found optimal living conditions and little competition for food and living space from other organisms.
The mass accumulations of scutellids in three layers within this bed are discussed by Nebelsick and Kroh (2002). Four different possible mechanisms for producing the observed mass accumulations are discussed: (1) storm-induced supratidal accumulation, (2) obrution, (3) proximal tempestites, and (4) in situ winnowing. Extant sand dollars are known to reach density values of over 1300 individuals $/ \mathrm{m}^{2}$ for the suspensionfeeding echinoid Dendraster excentricus, as well as over 500 individuals $/ \mathrm{m}^{2}$ for the deposit-feeding Mellita quinquiesperforata (Bell and Frey, 1969; Merril and Hobson, 1970; Penchaszadeh and Molinet, 1994; Tavares and Borzone, 1998). The detailed analysis of the deposit enabled interpreting the lower two layers as proximal storm deposits, whereas the uppermost layer was produced by in situ winnowing (Nebelsick and Kroh, 2002).

\subsection{Cidaroid-Echinacea Assemblage}

\subsubsection{Bed 5c-Description}

This bed is ca $50 \mathrm{~cm}$ thick and consists of a coarse-grained, poorly sorted, well-rounded sandstone. It is heavily bioturbated by large branched Thalassinoides-type burrows up to $5 \mathrm{~cm}$ in diameter which can extend more than $1 \mathrm{~m}$ horizontally. Well-rounded quartz grains dominate the sediment; well-rounded bioclasts (echinoderm fragments, mollusc shells and bryozoans) are common; occasional reworked clay clasts are also present. The bed is very fossiliferous. The most common fossils are spines and less commonly plates of the cidaroid Prionocidaris avenionensis (Fig. 3e-h) and fragments of pectinids and oysters. Celleporid bryozoans and fragments of undetermined scutellids and Echinolampas commonly occur. Furthermore, the coronas of small regular echinoids Arbacina monilis (Fig. 3i), Brochopleurus fourtaui (Fig. 3j) and Temnopleuridae indet. are present. Less common are Echinocyamus stellatus, Echinocyamus sp. A, fragments of undetermined spatangoids, balanid plates and the teeth of sharks and bony fish. Centrodorsals of comatulid crinoids are also present, but rare. Additionally, a high number of marginal ossicles of Astropecten were found. 


\subsubsection{Functional morphology and actualistic comparisons}

Prionocidaris avenionensis is a cidaroid with relatively long, slender primary spines with a trumpet-shaped whorl of thorns at the distal end. This feature can be interpreted as an adaptation to living on soft substrates. Fell (1966) reported that short-spined cidaroids live on hard bottoms or secondary hardgrounds, whereas forms with long slender spines tolerate soft bottoms. The living species Prionocidaris baculosa lives on coarse sand and gravel with coral patches or in coral carpets as well as on soft substrates (Nebelsick, 1992b). The small temnopleurid Arbacina monilis has no living congeneric relatives, but its morphology is generally similar to the Recent Psammechinus microtuberculatus. This species lives in shallow habitats on secondary hardgrounds or hides under stones and in seagrass or macroalgal patches (Göthel, 1992). Challis (1980) interpreted the related species Arbacina piae as a vagile epibiont on coarse sandy substrates of the shallow sublittoral.

The genus Brochopleurus is also extinct. It is, however, similar to Arbacina monilis in many features and may have occupied a similar habitat. Echinocyamus stellatus is rather similar to the Recent species Echinocyamus pusillus, which lives in the interstitial space of shell gravel and coarse sand (Mortensen, 1927; Kier, 1964; Smith, 1980a). This mode of life would fit well for the two fossil species of Echinocyamus found in this bed. However, not all extant species of Echinocyamus live in coarse sands. Nebelsick $(1992 \mathrm{a}, \mathrm{b})$ and Nebelsick and Kowalewski (1999), for example, describe Echinocyamus crispus from poorly sorted fine sands with seagrass and from other habitats. The occurrence of comatulid crinoids suggests the presence of a structured habitat, since many of these animals are nocturnal and hide in small crevices during daytime (Messing, 1997). Recent species of astropectinid sea stars are typical inhabitants of sandy bottoms and are sometimes associated with seagrass patches. They are carnivorous and prey on molluscs, other echinoderms and arthropods (Riedl, 1983; Zavodnik, 1988). The presence of relatively well-preserved, nonabraded spatangoid fragments, which show affin- ities to schizasterids, indicates that finer sediments than those observed in the field were present nearby.

\subsubsection{Palaeoenvironmental interpretation}

The palaeoenvironment is interpreted as the shallow sublittoral with fully marine conditions and moderate water energy. It represents a diverse habitat with coarse sandy bottoms as well as finer sediments. Additionally, sheltered habitats in the form of seagrass or macroalgal patches may have been present. Celleporid bryozoans probably provided secondary hardgrounds. This bed represents a slightly deeper habitat than that of bed 3. A similar habitat is reported by Kroh and Harzhauser (1999) from the Burdigalian of Austria. This differs only slightly from the assemblage described here by the absence of cidaroids and the presence of diadematid remains. This was also interpreted to represent a highly structured habitat; however, slightly shallower than the one described here.

\subsection{Transported Assemblage}

\subsubsection{Bed $7 b-$ Description}

This bed consists of a ca $40-\mathrm{cm}$ thick bivalve Planostegina shell bed, which lies directly above a Planostegina rudstone. The base of this layer is often not very sharp and is defined only by the higher number of bioclasts, since the matrix of the shell bed has the same lithology as the bed below. The bivalves in this bed consist of densely packed shells of pectinids and oysters, without preferred orientation (see Mandic and Piller, 2001). Both complete specimens as well as fragments are present. Further taphonomic features include bioerosion by clionid sponges, encrustation by balanid barnacles and bryozoan overgrowth.

Tellinid and venerid bivalves were also originally present, but are only preserved as moulds due to aragonite dissolution. Celleporid bryozoans, barnacles, Clypeaster martini (Fig. 5a), Clypeaster sp. A are less common. A few fragments of Echinolampas ampla and a single specimen of Schizechinus sp. (Fig. 5b) were also recovered. 


\subsubsection{Functional morphology and actualistic comparisons}

Clypeaster martini is interpreted as a shallow burrower due to its low test profile, thin margin and flat ventral surface. These features are typical for burrowing species of the genus Clypeaster (Kier and Grant, 1965; Poddubiuk and Rose, 1985). C. martini is rather similar to the extant species $C$. subdepressus, which lives in shallow water depths (most commonly between 5 and $50 \mathrm{~m}$ ) burrowing in coarse biogenic sand fields or shelly sediment with little or no seagrass (Kier and Grant, 1965; Hendler et al., 1995). Clypeaster sp. A, however, shows a tumid margin and a concave ventral surface with its peristome in an infundibulum, features which are characteristic of species with an epibenthic mode of life (Kier and Grant, 1965). Only a few fragments of the cassiduloid Echinolampas ampla were found in this bed. As discussed above, this genus prefers shallow-water, coarse sandy substrates.

The extinct regular echinoid genus Schizechinus was interpreted to occupy similar environments as Sphaerechinus granularis (see Roman, 1984; Borghi, 1993). This extant Mediterranean echinoid prefers firm bottoms, for example grass-stabilised sand-flats (Ried1, 1983) or shallow pebble bottoms close to rocky coasts (Ernst, 1973). The presence of $\mathrm{P} 2$ isopores in this form indicates that it lived in an environment with low to moderate water energy and was able to conceal itself with debris (compare Smith, 1978). The regular echinoid Schizechinus duciei from the Tortonian of the Maltese Islands is found associated with a coralline algal bioherm with an interpreted depth of $25 \mathrm{~m}$ or less (Challis, 1980). Néraudeau et al. (2001, p. 46, figure 4) found Schizechinus to be a component of their CMSS echinoid assemblage in the Messinian of the Sorbas Basin (Spain), which contains Clypeaster marginatus, Schizaster saheliensis and Spatangus purpureus and represents sandy limestone of the lower infralittoral. Additional information, especially on accompanying other biota, can be found in Lacour and Néraudeau (2000) and Saint Martin et al. (2000).

\subsubsection{Palaeoenvironmental interpretation}

As documented by Piller et al. (1998) and Mandic and Piller (2001), this shell bed represents a tempestite. The echinoids, along with the other organisms, were most probably transported from a shallower habitat. This represented predominantly coarse, sandy substrates occupied by $\mathrm{Cly}$ peaster and Echinolampas; firm substrates were also present, as documented by the presence of Schizechinus.

\subsection{Spatangoid Assemblage}

\subsubsection{Bed 8 - Description}

This bed consists of three very fossiliferous, intensively bioturbated layers $(8 \mathrm{a}-\mathrm{c}$, together ca 2.6 $\mathrm{m}$ thick), each showing a fining upwards sequence from coarse to fine calcareous sandstones, a nonfossiliferous sandstone (8d) and another fossiliferous bed (8e). The lowermost layer (bed $8 \mathrm{a}$ ) bears large foraminifers (Planostegina), pectinids, oysters, irregular echinoids, celleporid bryozoans, serpulids and moulds of turitellid gastropods. In the upper part of this layer, an accumulation of very well-preserved, articulated pectinids occurs. The next layer (bed $8 \mathrm{~b}$ ) bears an accumulation of pectinid shells, which lie subparallel to the bedding plane in the lowermost $15 \mathrm{~cm}$. Irregular echinoids, pectinids and larger foraminifers (Planostegina) occur occasionally throughout the layer. The uppermost layer (bed 8c) begins with a $15-\mathrm{cm}$ thick pectinid shell bed of densely packed, whole, articulated as well as single, valves and fragments. Only a few of the shells show signs of bioerosion by clionid sponges and overgrowth by oysters. Additionally, complete as well as fragmented specimens of Clypeaster martini occur in the shell bed. Pectinids and irregular echinoids occur only occasionally in the rest of the layer.

The irregular echinoids found in these layers consist solely of burrowing forms. The most common species is Schizaster eurynotus (Fig. 5d). Other echinoids, including Pericosmus latus (Fig. 5g), Brissopsis crescenticus (Fig. 5e,f), Trachyaster? cotteaui (Fig. 5c), Spatangus (Platyspatus) sp. 


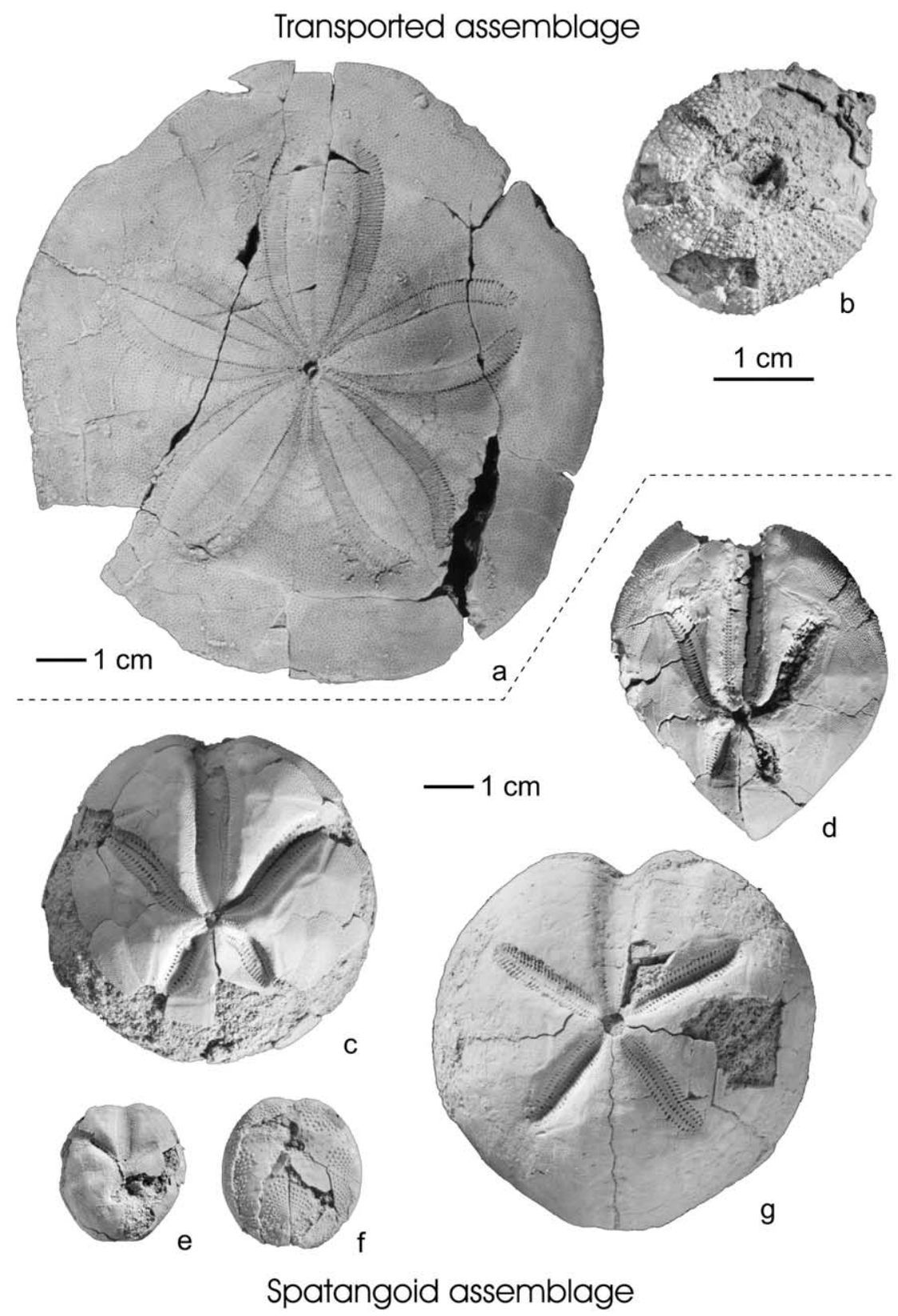

Fig. 5. Species composition of echinoid assemblages. Transported Assemblage: (a) Clypeaster martini Des Moulins, 1837; (b) Schizechinus sp.; Spatangoid assemblage: (c) Trachyaster? cotteaui (Wright, 1855); (d) Schizaster eurynotus Agassiz, 1841; (e,f) Brissopsis crescentica Wright, 1855; (g) Pericosmus latus (Desor, 1847).

and Spatangus (Phymapatagus) sp., are relatively rare. The proportional representation of each species is shown in Fig. 6.

Bed $8 \mathrm{e}$ consists of $35 \mathrm{~cm}$ of medium sandstones containing small pectinids, branched and globular bryozoans, larger foraminifers (Planostegina) and the occasional irregular echinoid. The most common echinoid species are Schizaster eurynotus and 


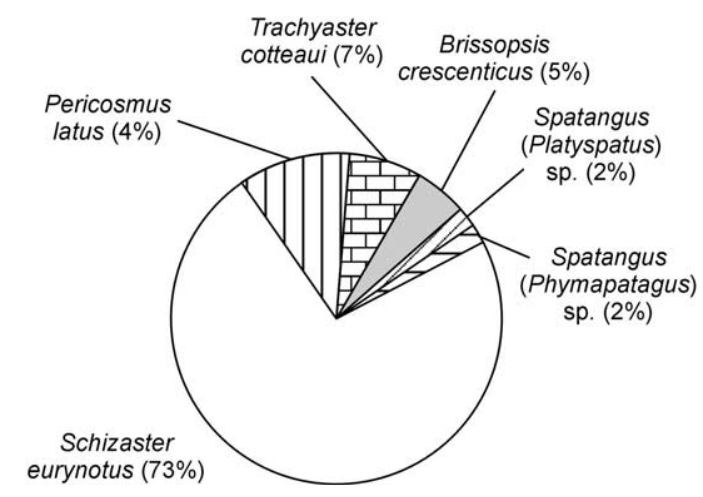

Fig. 6. Relative abundances of the different echinoid species in bed $8 \mathrm{a}-\mathrm{c}$.

Pericosmus latus, less common are Brissopsis crescenticus and Trachyaster? cotteaui.

\subsubsection{Functional morphology and actualistic comparisons}

Schizaster eurynotus, the most common echinoid, was interpreted by Rose and Watson (1998) as a shallow-burrowing mud dweller similar to the Recent Mediterranean species Schizaster canaliferus. Their material originates from mudstones of the Globigerina Limestone of the Maltese Islands. In the Gebel Gharra section, however, Schizaster eurynotus occurs in fine- to medium-grained sandstones where it is commonly found in life position. Contrary to Rose and Watson (1998), this species is interpreted here as a deep-burrowing deposit feeder due to its wedgeshaped test, deep frontal ambulacrum with welldeveloped partitioned isopores and a large number of respiratory elongated isopores in the petals, which represent adaptations for deeper burrowing (compare Smith, 1980b). Additionally, this echinoid has subanal partitioned isopores, which are associated with funnel-building tube feet (compare Smith, 1980b). Furthermore, a posterior-situated apical system, a high keel in interambulacrum 5, long curved anterior-paired petals and short posterior-paired petals were interpreted as an adaptation to deeper burrowing by McNamara and Philip (1980). It thus seems very likely that Schizaster eurynotus was not restricted to sediments of a particular grain size. This encompasses shallow burrowing in mud as documented by
Rose and Watson (1998) as well as deeper burrowing in silty to sandy sediments as documented here. The burrowing depth seems to be influenced by the depth of the redox-potential-discontinuity layer (RDP layer), which itself is related to the particle size of the sediment. Schizaster canaliferus was found to be confined to the upper, oxygenated layers of the sediment, above the RDP layer (Schinner, 1993). Extant species of the genus Schizaster are known to live in fine-grained sediments, burrowing up to $25 \mathrm{~cm}$ deep (e.g. Schizaster (Paraster) floridiensis Kier and Grant, 1965; Smith, 1980a).

Pericosmus latus is a species that does not seem to be well adapted to deep burrowing. This echinoid has small partitioned isopores in the shallow frontal ambulacrum and a rather high profile, with the apical system lying centrally. It is interpreted here as a shallow-burrowing form. Unfortunately, little is known about the extant species of the genus Pericosmus, but they seem to be most common in deeper habitats. Mortensen (1951) reported them from 18 to $486 \mathrm{~m}$ depth in mud and sand, with their highest abundance at 200-300 m.

Brissopsis crescenticus is similar to the extant species Brissopsis elongata, which is reported from muddy substrates, burrowing in depths between 4 and $10 \mathrm{~cm}$ (Kier, 1975). Brissopsis lyrifera, on the contrary, lives in mud, sandy mud or silty substrates, with its dorsal surface not deeper than $1 \mathrm{~cm}$ below the sediment surface (Smith, 1980a). This variation makes an interpretation of burrowing depth for Brissopsis crescenticus difficult. Furthermore, only few, poorly preserved specimens of the fossil species were available for study, thus impairing possible inferences from test and pore morphology.

The morphology of Trachyaster? cotteaui indicates that it lived burrowing in fine sediments. The deep frontal ambulacrum, the large, curved anterior petals and the small posterior petals can be interpreted as adaptations to deeper burrowing if these features have the same functional morphology as in Schizaster. According to Néraudeau (1994), Trachyaster populated deep outer-platform environments in the Mediterranean during the Lower and Middle Miocene. 
The two subgenera of Spatangus (Platyspatus and Phymapatagus) reported here are both restricted to the fossil record. The presence of non-conjugate anisopores in the frontal ambulacrum of Platyspatus, respectively small partitioned isopores in the frontal ambulacrum of Phymapatagus, and the only slightly depressed frontal ambulacrum in both forms indicates that both species ploughed the sediment surface or were shallow burrowers (compare Smith, 1980a). In fact, extant species of the genus Spatangus (Spatangus) which live in fine sand are not completely buried, but plough the sediment surface (e.g. Spatangus raschi, Smith, 1980a).

\subsubsection{Palaeoenvironmental interpretation}

The palaeoenvironment of this bed is interpreted as deeper sublittoral, with low water energy and muddy to silty substrate. The presence of six different species of deposit-feeding echinoids in the same habitat can be explained by their different burrowing depths. Spatangus (Phymapatagus) sp. and Spatangus (Platyspatus) sp. most probably ploughed the sediment surface, whereas Brissopsis crescenticus and Pericosmus latus were shallow to moderately deep burrowing forms. Trachyaster? cotteaui burrowed even deeper and Schizaster eurynotus probably was a very deep burrower. The occasional occurrences of Clypeaster martini are restricted to the pectinid shell beds and are thus interpreted as representing transported, allochthonous elements.

\subsection{Mixed Assemblage}

\subsubsection{Beds 11 and $12 a$ - Description}

Bed 11 is a $30-\mathrm{cm}$ thick conglomerate, which has a glauconitic silty limestone matrix and reworked claystone components, which are often incrusted by bryozoans. Pectinids, oysters (Anomia sp.) and moulds of gastropods are relatively common. Less prevalent are the small regular echinoid Psammechinus dubius var. coronalis (Fig. $7 \mathrm{f}-\mathrm{h}$ ), spines of Prionocidaris avenionensis (Fig. 7c-e), fragments of Clypeaster and undetermined spatangoids as well as bryozoans and poritid corals.

Bed 12a is about $40 \mathrm{~cm}$ thick and consists of glauconitic limestones with reworked clay clasts. It is highly fossiliferous, but the biogenic content decreases upwards. Pectinids, spines and less commonly plates of the cidaroid Prionocidaris avenionensis (Fig. 7b-e) are the most common fossils. Less common are solitary corals, branched and crustose bryozoans, serpulid macroids, fragments of undetermined spatangoids and Clypeaster, as well as shark teeth. The spatangoid Pericosmus latus (Fig. 7a) is rare.

\subsubsection{Functional morphology and actualistic comparisons}

These two beds are considered together in the palaeoenvironmental analysis because of their lithological similarity and faunal affinities. As discussed above, Prionocidaris avenionensis is interpreted to be an epifaunal inhabitant of sandy substrates. Psammechinus dubius var. coronalis most probably lived similarly to the extant species Psammechinus microtuberculatus, which lives in shallow habitats on secondary hardgrounds or which hides under stones and in seagrass or macroalgal patches (Göthel, 1992). The presence of Pericosmus latus and fragments of other undetermined spatangoids indicate a soft bottom with moderate to low water energy. Clypeaster also suggests shallower water depths.

\subsubsection{Palaeoenvironmental interpretation}

The palaeoenvironment of these two beds is interpreted as the shallow sublittoral with low to moderate water energy. Sandy soft bottom habitats, possibly with seagrass or algal patches, with larger clay clasts were occupied by shallow-burrowing spatangoids, epifaunal pectinids, gastropods and regular echinoids. Furthermore, sessile organisms such as corals and bryozoans occurred. The glauconite within the sediment may suggest reduced sedimentation, an interpretation also supported by the high fossil content.

\subsection{Clypeaster martini Assemblage}

\subsubsection{Bed 15-16.1-Description}

These two beds together are nearly $8 \mathrm{~m}$ thick and consist of a coarse sandstone in the lower part that gradually changes into a calcareous 


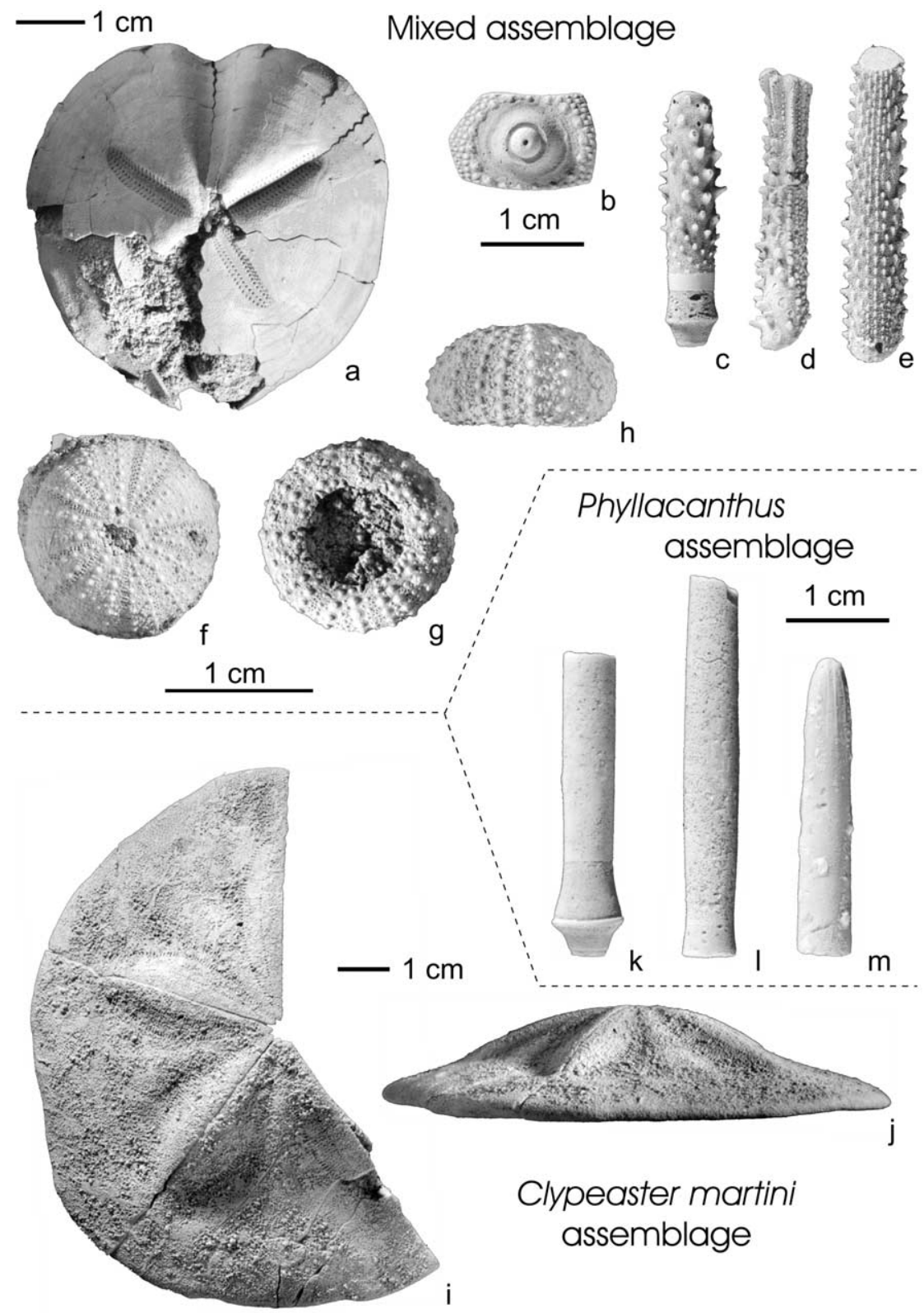

Fig. 7. Species composition of echinoid assemblages. Mixed Assemblage: (a) Pericosmus latus (Desor, 1847); (b-e) Prionocidaris avenionensis (Des Moulins, 1837) (b, interambulacral plate; c, spine base; d, spine tip; e, spine shaft); (f-h) Psammechinus dubius var. coronalis (Lambert, 1910); Clypeaster martini assemblage: (i,j) Clypeaster martini Des Moulins, 1837; Phyllacanthus assemblage: $(\mathrm{k}-\mathrm{m})$ Phyllacanthus sp. (k, spine base; 1 , spine shaft; $\mathrm{m}$, spine tip).

sandstone in the upper part of each bed. The base of the lower bed is erosive and bears rounded and angular clay clasts. Two layers of oysters, which are partly fragmented and heavily bored, can be found in the upper part of the lower bed. Pectinids, moulds of Veneridae and Cardiidae, and coralline algae are relatively common. Additionally, fragments of Clypeaster martini (Fig. 7i,j) 
and Scutellidae indet., as well as balanids and bryozoans, occasionally occur.

\subsubsection{Functional morphology and actualistic comparisons}

As discussed above, Clypeaster martini is interpreted as a shallow-burrowing endobenthic echinoid living in shallow-water, sandy substrates. Although the remains of Scutellidae indet. are fragmentary, it is clear from their morphology that these sand dollars differ from the other scutellid (Parascutella deflersi) found in this section. As in $P$. deflersi, the presence of a rather thick shell, flat profile, thin margin and internal support structures indicate an adaptation to shallow highenergy habitats (see above).

\subsubsection{Palaeoenvironmental interpretation}

This bed represents a sandy, shallow-water, higher-energy habitat similar to that of beds 3-4. The low abundance of echinoids, however, suggests that living conditions were not as optimal, resulting in a lower density of living echinoids.

\subsection{Phyllacanthus Assemblage}

\subsubsection{Bed 27 - Description}

This bed is ca $4.5 \mathrm{~m}$ thick and consists of floatstones with a packstone matrix. It bears oysters, thin coralline algal crusts and spines of the cidaroid Phyllacanthus sp. (Fig. 7k-m). This bed constitutes an exception, as echinoids are generally rare in the carbonate-dominated upper part of the Gebel Gharra section. Only a few Clypeaster, undetermined scutellids and Echinolampas were present. The very hard lithology, however, precluded collection in most cases. The few specimens that were collected from weathered material were mostly fragmented and highly abraded.

\subsubsection{Functional morphology and actualistic comparisons}

Extant species of the genus Phyllacanthus are confined to marine environments in which the sea surface temperature does not fall below ca $15^{\circ} \mathrm{C}$ in winter (Fell, 1954). These are epibenthic organisms feeding on a wide variety of available food sources, including macroalgae and inverte- brates (Fell, 1966). Phyllacanthus imperialis from the Red Sea and the Indian Ocean lives on reef substrates and on coral patches within moderately sorted coarse sands (Nebelsick, 1992b).

\subsubsection{Palaeoenvironmental interpretation}

This bed represents a shallow-marine, coarse sandy carbonate environment. Only the robust primary spines of the cidaroids are preserved. The other skeletal elements of these echinoids, including the comparatively large and robust interambulacral plates, seem to have been destroyed by taphonomic processes.

\section{Discussion}

The interpretations of environmental gradients within the section are made following sedimentological trends as well as the detailed investigation of echinoids described above. These include mode of life derived from functional morphology, taphonomic patterns based on preservation, interpretation of autochthonous and allochthonous occurrences, changes in diversity patterns and in ecological resources. In general, there is a broad variation of life habits represented by the echinoids (Table 2). These include epifaunal dwellers, surface ploughers, as well as shallow and deep infaunal burrowers. Reconstructed substrates include secondary hardgrounds, seagrass as well as sand and muddy soft substrates. Water energy conditions ranged from high to low.

The general transgression/regression cycle as reported by Abdelghany and Piller (1999) and Mandic and Piller (2001) is substantiated by the changing echinoid assemblages. The first four assemblages show a tendency towards deeper-water conditions, in keeping with the ongoing transgression (Fig. 8). This is accompanied by the transition from highly mobile to more stable substrates, from extensive coarse sands to a highly structured environment including both hard and soft substrates, then finally towards monotonous finer sediments. The transported assemblage is more difficult to interpret, as it represents an allochthonous assemblage, highly subject to taphonomic bias. The last three assemblages, although poor in 


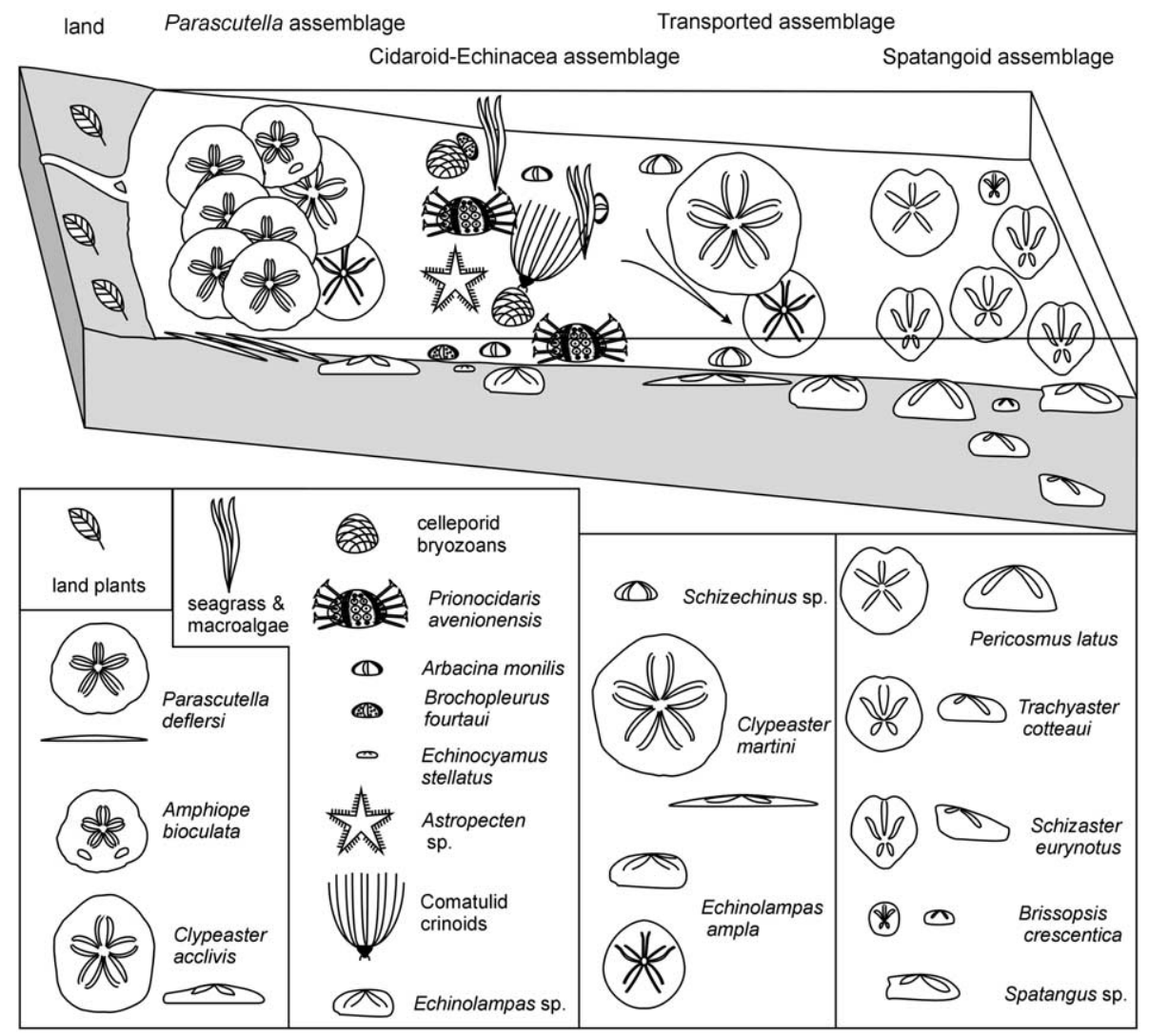

Fig. 8. Reconstruction of the first four echinoid assemblages within a transgression scenario. The assemblages reflect increasingly deep environments.

echinoids, clearly represent a shallowing upward tendency culminating in shallow-water carbonates.

The Parascutella Assemblage shows the most spectacular sedimentary structures and by far the highest density of echinoid skeletons due to concentrating effects of proximal tempestites and winnowing. It shows, however, a relatively low diversity, which may reflect the extreme environmental conditions and/or taphonomic effects. The Parascutella Assemblage at the base of the Lower Miocene marine sediments represents a shallowwater, high-energy, shoreface environment. This environment was very conducive to a very large population of the sand dollar Parascutella deflersi. Storm events led to mass accumulations of these echinoids within proximal tempestites. Winnowing also led to high-density echinoid shell concentrations. The other recovered echinoids are also typical for shallow-water, higher-energy, mobile sediments. The high stability of clypeasteroids with interlocking plates and internal supports and cassiduloids with their thick skeletons was conducive to their preservation as complete tests or larger test fragments in this environment. The echinoids represent a time-averaged collection, as both well-preserved as well as heavily abraded, fragmented, bioeroded and encrusted skeletons occur together.

The Cidaroid-Echinacea Assemblage represents a slightly deeper, moderate-energy environment within a highly structured habitat. The high diversity of this assemblage is due to varied substrate conditions, including coarser- and finer-grained soft sediments, secondary hardgrounds and possibly seagrass, which enabled both epifaunal regular as well as shallow infaunal irregular sea urchins to flourish in this habitat. The higher diversity may 
also have profited from quieter water conditions, allowing the preservation of smaller regular echinoids as well as larger fragments of cidaroid tests.

The Transported Assemblage represents an allochthonous collection of echinoids from shallowwater, coarse sandy substrates, which were included in tempestites. Taphonomic effects of transport could obviously have affected the taxonomic make-up of the echinoid fauna, as these are restricted to more resistant, thicker-shelled Clypeaster and Echinolampas. The presence of two different Clypeaster morphologies (sediment/water interface and shallow infaunal) suggests a sandy environment where different food resources were utilised. This represented a somewhat higher-energy environment, though not as high as the Parascutella Assemblage.

Further upwards, a deeper, low-energy environment with a rich fauna of deposit-feeding echinoids is represented by the Spatangoid Assemblage. This echinoid assemblage represents the lowest energy conditions. Relatively high sea-urchin diversity is a result of tiering of different burrowing depths of echinoids exploiting different food sources. Intense bioturbation of sediments results. Taphonomic bias is low, with reduced energy conditions allowing thin-shelled spatangoids to be preserved as complete tests.

Above this horizon thick, non-fossiliferous marls occur, which represent the deepest water facies of the section. From then on shallowing upward development culminating in a shallowwater carbonate environment with corals and coralline red algae starts. These marls are terminated by glauconitic sandstones and limestones containing the Mixed Assemblage, representing a slightly shallower, low-to moderate-energy environment. Reduced sedimentation may have resulted in a time-averaged accumulation of echinoids from different environments. A wide variety of substrates is thus suggested by the echinoid fauna. These include cidaroids tolerant of sandy substrates; echinaceans, suggesting secondary hardgrounds or seagrass presence; thin-shelled spatangoids, indicating soft bottoms with low to moderate water energy and thicker-shelled clypeasteroids from coarser substrates.

The shallowing upward trend in the upper part of the section is also supported by the next echinoid assemblage, dominated by the name-giving Clypeaster martini. These represent a shallow, higher-energy environment. These coarse sands and calcareous sandstones, however, did not support high populations of clypeasteroids as in the Parascutella Assemblage found towards the base of the section.

The sediments towards the top of the section represent a shallow-water carbonate development. This is reflected by the presence of the genera Clypeaster, Echinolampas and Phyllacanthus, as well as undetermined scutellids. The low diversity and low abundance of recorded echinoids in this environment is, however, surprising given the species richness in recent reefal and other carbonate environments (Nebelsick, 1996; Carter, 1997). The preservation within the Phyllacanthus Assemblage, however, suggests that taphonomic bias along with collection bias may be responsible. The fact that only robust spines are present suggests that high-energy environment has destroyed other skeletal elements. In fact, although hard substrates in reefal environments show a higher diversity through a number of regular echinoids, these show a much lower preservation potential than irregular echinoids in neighbouring soft substrates (Kier, 1977; Nebelsick, 1996). This is, in part, due to the fact that not all regular echinoids in reefal environments possess massive spines conducive to preservation in higher-energy conditions. A collection bias is probably also present, as these sediments are present as hard limestone in poorly accessible vertical cliffs. This is in stark contrast to the other echinoid-yielding sediments within the section, which are easily accessible and are readily weathered, providing for numerous specimens in the field.

A similar, but slightly different approach to the study presented here was applied by Néraudeau et al. (2001) to Messinian echinoid assemblages of the Sorbas Basin (Spain). An ecomorphological gradient was defined for the stratigraphical succession of four irregular echinoid associations based on the bathymetric distribution of extant Mediterranean echinoids. The spatio-temporal variations of this gradient were used to interpret local palaeoenvironmental changes as well as re- 
gressive and transgressive pulses within the studied sections (Néraudeau et al., 2001).

The succession of the echinoid assemblages in the Gebel Gharra section can also be seen to represent an ecomorphological gradient with the shallow-water Parascutella Assemblage and the deeper-water Spatangoid Assemblage as end members during the transgression (Fig. 8). The following regression eventually led to the Phyllacanthus Assemblage, which again represents shallow-water conditions. Contrary to the example from Néraudeau et al. (2001), however, the stratigraphical succession of the echinoid assemblages described here is not affected by short-term regressive pulses. The use of the ecomorphological gradient method, shown to work very well in platform settings (e.g. Néraudeau, 1991, 1992; Néraudeau and Floquet, 1991; Néraudeau et al., 2001), is thus limited in the marginal setting of the Suez area.

\section{Conclusions}

(1) The study of echinoid faunas recovered from the Gebel Gharra section, Eastern Desert, Egypt, illustrates how palaeoecological interpretations of successive echinoid assemblages can be employed as a tool to investigate large-scale patterns of environmental changes within a section.

(2) Seven different echinoid assemblages were recovered, ranging from high-energy, shoreface environments with mass clypeasteroid accumulations, a diverse mixed assemblage representing various substrates and life habits, a diverse spatangoid-dominated assemblage with species showing various burrowing depths to a poorly diverse cidaroid spines assemblage within shallow-water carbonates.

(3) The functional morphological approach combined with actualistic comparisons allows for the very detailed investigation of life habitats. This enabled a comprehensive interpretation of palaeoenvironments for the seven different echinoid assemblages.

(4) Differences of diversity within the assemblages can be correlated to substrate variation, burrowing depths as well as taphonomic factors.
Disarticulation and fragmentation along with collection bias are probably responsible for the low apparent diversity of the shallow-water carbonate environment. The assemblages represent autochthonous communities, within-facies transport (proximal tempestites) as well as out-of-facies transport of echinoid material.

(5) The general transgression/regression cycle seen in sedimentary developments with siliciclastics at the base and shallow-water carbonates at the top of the section is very well reflected by changes of echinoid assemblages. These at first show a deepening and then a shallowing upward cycle of palaeoenvironments.

\section{Acknowledgements}

This study was supported by the German Science Foundation (DFG): Project No. NE537/5-1 to J.H.N. (University of Tübingen) and STE $857 /$ 1-1 to Fritz F. Steininger (Senckenberg Museum, Frankfurt), and the Austrian Science Foundation: Project No. P11886-GEO and P-14366-Bio to Werner E. Piller (University of Graz). Thanks to Didier Néraudeau and Andrew B. Smith for their critical reviews and improving comments. We wish to thank Osman Abdelgany, Mathias Harzhauser, Oleg Mandic, Werner Piller, Jürgen Schlaf, and Frithjof Schuster for help in the field and critical discussion. Alice Schumacher is gratefully acknowledged for the photographs. Special thanks also to the Geological-Palaeontological Department of the Natural History Museum Vienna, which provided research infrastructure, library and collection access.

\section{References}

Abdelghany, O., Piller, W.E., 1999. Biostratigraphy of Lower Miocene sections in the Eastern Desert (Cairo - Suez district, Eygpt). Rev. Micropaléontol. 18, 607-617.

Beadle, S.C., 1989. Ontogenetic regulatory mechanisms, heterochrony, and eccentricity in dendrasterid sand dollars. Paleobiology 15, 205-222.

Bell, B.M., Frey, R.W., 1969. Observations on ecology and the feeding and burrowing mechanisms of Mellita quinquiesperforata (Leske). J. Paleontol. 43, 553-560. 
Bentley, A.C., Cockcroft, A.C., 1995. Sublittoral sand dollar (Echinodiscus bisperforatus) communities in two bays on the South African coast. S. Afr. J. Zool. 30, 5-18.

Birkeland, C., Chia, F.-S., 1971. Recruitment risk, growth, age and predation in two populations of sand dollars, Dendraster excentricus (Eschscholtz). J. Exp. Mar. Biol. Ecol. 6, 265-278.

Blanckenhorn, M., 1901. Neues zur Geologie und Palaeontologie Aegyptens. III Das Miozän. Z. Dtsch. Geol. Ges. 53, 52-132.

Boggild, G.R., Rose, E.P.F., 1984. Mid-Tertiary echinoid biofacies as palaeoenvironmental indices. Ann. Géol. Pays Hellén. 32, 57-67.

Borghi, E., 1993. Nuove acquisizioni relative a: Schizechinus serialus Pomel, 1887. Echinodermi fossili emiliani - II. Boll. Soc. Regg. Sci. Nat. 13, 1-11.

Carter, B.D., 1997. Inferring substrate preferences from test morphology in echinoids, and interpreting spatial and temporal patterns of diversity. Paleontol. Soc. Pap. 3, 121145.

Carter, B.D., Beisel, T.H., Branch, W.B., Mashburn, C.M., 1989. Substrate preferences of late Eocene (Priabonian/Jacksonian) echinoids of the eastern Gulf Coast. J. Paleontol. 63, 495-503.

Challis, G.R., 1980. Palaeoecology and Taxonomy of MidTertiary Maltese Echinoids. Ph.D. Thesis (unpublished). Department of Geology, Bedford College, University of London, London, $401 \mathrm{pp}$.

Dodd, J.R., Alexander, R.R., Stanton, R.J., 1985. Population dynamics in Dendraster, Merriamaster and Anadara from the Neogene of the Kettleman Hills, California. Palaeogeogr. Palaeoclimatol. Palaeoecol. 52, 61-76.

Ebert, T.A., Dexter, D.M., 1975. A natural history study of Encope grandis and Mellita grantii, two sand dollars in the Northern Gulf of California, Mexico. Mar. Biol. 32, 397407.

Ernst, G., 1973. Aktuopaläontologie und Merkmalsvariabilität bei mediterranen Echiniden und Rückschlüsse auf die Ökologie und Artumgrenzung fossiler Formen. Paläontol. Z. 47, $188-216$.

Fell, H.B., 1954. Tertiary and Recent Echinoidea of New Zealand: Cidaridae. Paleontol. Bull. Geol. Surv. N. Z. 23, 1-62.

Fell, H.B., 1966. Cidaroids. In: Moore, R.C. (Ed.), Treatise on Invertebrate Paleontology, U. Echinodermata. GSA and Univ. Kansas Press, Lawrence, KS, pp. U312-U340.

Fuchs, T., 1878. Die Geologische Beschaffenheit der Landenge von Suez. Denkschr. Kaiserl. Akad. Wiss. Math.-Naturw. Cl. $38,25-42$.

Fuchs, T., 1883. Beiträge zur Kenntniss der Miocänfauna Ägyptens und der libyschen Wüste. Palaeontographica 30, $18-66$.

Ghiold, J., Hoffman, A., 1984. Clypeasteroid echinoids and historical biogeography. N. Jb. Geol. Paläontol. Mh. 1984, 529-538.

Ghiold, J., Hoffman, A., 1986. Biogeography and biogeographic history of clypeasteroid echinoids. J. Biogeogr. 13, 183-206.
Göthel, H., 1992. Farbatlas Mittelmeerfauna. Niedere Tiere und Fische. Eugen Ulmer Verlag, Stuttgart, 318 pp.

Hendler, G., Miller, J.E., Pawson, D.L., Kier, P.M., 1995. Sea Stars, Sea Urchins, and Allies. Echinoderms of Florida and the Carribean. Smithsonian Institute Press, Washington, DC, 380 pp.

Kanazawa, K., 1992. Adaption of test shape for burrowing and locomotion in spatangoid echinoids. Palaeontology 35, 733-750.

Kier, P.M., 1964. Fossil echinoids from the Marshall Islands. Geol. Surv. Prof. Pap. 260-G, 1121-1126.

Kier, P.M., 1972. Upper Miocene echinoids from the Yorktown Formation of Virginia and their environmental significance. Smiths. Contrib. Paleobiol. 13, 1-41.

Kier, P.M., 1975. The echinoids of Carrie Bow Cay, Belize. Smiths. Contrib. Zool. 206, 1-45.

Kier, P.M., 1977. The poor fossil record of the regular echinoid. Paleobiology 3, 168-174.

Kier, P.M., Grant, R.E., 1965. Echinoid distribution and habits, Key Largo Coral Reef Preserve, Florida. Smiths. Misc. Collns. 149, 1-68.

Kroh, A., 2000. Lower Miocene echinoids from Gebel Gharra, Egypt. Diploma Thesis. (unpublished). Institut für Paläontologie, Universität Wien, Vienna, $153 \mathrm{pp}$.

Kroh, A. (submitted). Lower Miocene echinoids from Gebel Gharra, Egypt. Abh. Senckenb. Naturforsch. Ges.

Kroh, A., Harzhauser, M., 1999. An echinoderm fauna from the Lower Miocene of Austria: Paleoecology and implications for Central Paratethys paleobiogeography. Ann. Naturhist. Mus. Wien 101A, 145-191.

Lacour, D., Néraudeau, D., 2000. Évolution de la diversité des Brissopsis (Echinoida, Spatangoida) en Méditerranée depuis la 'crise messinienne': application paléoécologique aux B. lyrifera intragypses de Sorbas (SE Espagne). Geodiversitas 22, 509-523.

Mandic, O., Piller, W.E., 2001. Pectinid coquinas and their palaeoenvironmental implications - examples from the early Miocene of northeastern Egypt. Palaeogeogr. Palaeoclimatol. Palaeoecol. 172, 171-191.

McKinney, M.L., 1985. The abundant occurrence of the Middle Miocene sand dollar Abertella aberti in the Hawthorne Formation of Florida. Southeastern Geol. 24, 155-158.

McNamara, K.J., Philip, G.M., 1980. Tertiary species of Echinolampas (Echinoidea) from southern Australia. Mem. Nat. Mus. Victoria 41, 1-14.

Merril, R.J., Hobson, E.S., 1970. Field observations of Dendraster excentricus, a sand dollar of western North America. Am. Midland Nat. 83, 595-624.

Messing, C.G., 1997. Living Comatulids. In: Waters, J.A., Maples, C.G. (Eds.), Geobiology of Echinoderms. Paleontol. Soc. Pap. 3, pp. 3-30.

Mortensen, T., 1927. Handbook of the Echinoderms of the British Isles. Humphrey Milford, Oxford Univ. Press, London, $471 \mathrm{pp}$.

Mortensen, T., 1948. A Monograph of the Echinoidea, IV, 1 Holectypoida, Cassiduloida. C.A. Reitzel, Copenhagen, 371 pp. 
Mortensen, T., 1951. A Monograph of the Echinoidea, V, 2 Spatangoida, Amphisternata II. C.A. Reitzel, Copenhagen, 593 pp.

Nebelsick, J.H., 1992a. Echinoid distribution by fragment identification in the Northern Bay of Safaga, Red Sea, Egypt. Palaios 7, 316-328.

Nebelsick, J.H., 1992b. The Northern Bay of Safaga (Red Sea, Egypt): An actuopalaeontological approach III. Distribution of echinoids. Beitr. Paläontol. Österr. 17, 5-79.

Nebelsick, J.H., 1996. Biodiversity of shallow-water Red Sea echinoids: implications for the fossil record. J. Mar. Biol. Ass. UK 76, 185-194.

Nebelsick, J.H., 1999. Taphonomic comparison between Recent and fossil sand dollars. Palaeogeogr. Palaeoclimatol. Palaeoecol. 149, 349-358.

Nebelsick, J.H., Kowalewski, M., 1999. Drilling predation on Recent clypeasteroid echinoids from the Red Sea. Palaios $14,127-144$.

Nebelsick, J.H., Kroh, A., 2002. The stormy path from life to death assemblages: The formation and preservation of mass accumulations of fossil sand dollars. Palaios 17, 378-393.

Néraudeau, D., 1991. Lateral variations of size-frequency distribution in a fossil echinoid community and their palaeoecological significance. Lethaia 24, 299-309.

Néraudeau, D., 1992. Transgressions - regressions and echinoid morphoclines. Lethaia 25, 219-220.

Néraudeau, D., 1994. Hemiasterid echinoids (Echinodermata: Spatangoida) from the Cretaceous Tethys to the present-day Mediterranean. Palaeogeogr. Palaeoclimatol. Palaeoecol. $110,319-344$

Néraudeau, D., 1995. Diversité des échinides fossiles et reconstitutions paléoenvironnementales. Geobios M.S. 18, 337345 .

Néraudeau, D., Floquet, M., 1991. Les échinides Hemiasteridae: marqueurs écologiques de la plateforme castillane et navarro-cantabre (Espagne) au Crétacé supérieur. Palaeogeogr. Palaeoclimatol. Palaeoecol. 88, 265-281.

Néraudeau, D., Goubert, E., Lacour, D., Rouchy, J.M., 2001. Changing biodiversity of Mediterranean irregular echinoids from the Messinian to Present-Day. Palaeogeogr. Palaeoclimatol. Palaeoecol. 175, 43-60.

Penchaszadeh, P.E., Molinet, R., 1994. Population ecology of the sand dollar Mellita quinquiesperforata latiambulacra Clark, 1940 on the west-central coast of Venezuela. In: David, B., Guille, A., Féral, J.-P., Roux, M. (Eds.), Echinoderms through Time. Proc. of the 8th Int. Echinoderm Conf., Dijon, 6-10 Sept. 1993. A.A. Balkema, Rotterdam, pp. 827-834.

Philippe, M., 1998. Les Échinides miocènes du Bassin du Rhône: révision systématique. Nouv. Arch. Mus. Hist. Nat. Lyon 36, pp. 3-241, 249-441.

Piller, W.E., Abdelghany, O., Kroh, A., Mandic, O., Nebelsick, J.H., Schlaf, J., Schuster, F., 1998. Transgressive Folgen und Lumachellenbildungen in einer untermiozänen Abfolge der Östlichen Wüste (Gebel Gharra, W' Suez, Ägypten). Erlanger Geol. Abh. Sonderband 2, 74-75.

Poddubiuk, R.H., Rose, E.P.F., 1985. Ecostratigraphic signifi- cance of morphological variation in the echinoid Clypeaster. Proc. VIIth Congress, I.U.G.S. Regional Comm. on Mediter. Neogene Strat., Budapest, Hung. Geol. Survey, pp. 463 465.

Riedl, R. (Ed.), 1983. Fauna und Flora des Mittelmeeres. 3rd edn. Paul Parey Verlag, Hamburg, 836 pp.

Roman, J., 1965. Morphologie et évolution des Echinolampas (Echinides, Cassiduloïdes). Mém. Mus. Natn. Hist. Nat. (Science Terre) Sér. C 15, 1-341.

Roman, J., 1984. Les échinides et les milieux de vie du Tertiaire, Quelques exemples. Géobios, Mém. Spéc. 8, 115-124.

Roman, J., Philippe, M., 1978. L'Echinolampas (Echinoidea, Cassiduloida) le plus proche de la métamorphose, dans le Miocène inférieur du Vaucluse (sud-est de la France). Ann. Paléontol. 64, 79-90.

Rose, E.P.F., Watson, A.C., 1998. Burrowing adaptions of schizasteroid echinoids from the Globigerina Limestone (Miocene) of Malta and their evolutionary significance. In: Mooi, R., Telford, M. (Eds.), Echinoderms: San Francisco. Proc. 9th Int. Echinoderm Conf., San Francisco, CA, 5-9 Aug. 1996. A.A. Balkema, Rotterdam, pp. 811-817.

Said, R., 1990. The Geology of Egypt. A.A. Balkema, Rotterdam, $734 \mathrm{pp}$.

Saint Martin, J.-P., Néraudeau, D., Lauriat-Rage, A., Goubert, E., Secrétan, S., Babinot, J.-F., Boukli-Hacene, S., Pouyet, S., Lacour, D., Pestrea, S., Conesa, G., 2000. La faune interstratifiée dans les gypses messiniens de Los Yesos (Bassin de Sorbas, SE Espagne): implications. Géobios 33, 637-649.

Schinner, G.O., 1993. Burrowing behaviour, substratum preference, and distribution of Schizaster canaliferus (Echinoidea: Spatangoida) in the Northern Adriatic sea. Mar. Ecol. 14, 129-145.

Seilacher, A., 1979. Constructional morphology of sand dollars. Paleobiology 5, 191-221.

Smith, A.L., 1981. Comparison of macrofaunal invertebrates in sand dollar (Dendraster excentricus) beds and in adjacent areas free of sand dollars. Mar. Biol. 65, 191-198.

Smith, A.B., 1978. A functional classification of the coronal pores of regular echinoids. Palaeontology 21, 759-789.

Smith, A.B., 1980a. The structure and arrangement of echinoid tubercles. Philos. Trans. R. Soc. London B 289, 1-54.

Smith, A.B., 1980b. The structure, function, and evolution of tube feet and ambulacral pores in irregular echinoids. Palaeontology 23, 39-83.

Smith, A.B., 1980c. Stereom microstructure of the echinoid test. Spec. Pap. Palaeontol. 25, 1-81.

Smith, A.B., 1984. Echinoid Palaeobiology. Allen and Unwin, London, $\mathrm{x}+190 \mathrm{pp}$.

Smith, A.B., Ghiold, J., 1982. Roles for holes in sand dollars (Echinoidea); a review of lunule function and evolution. Paleobiology 8, 242-253.

Smith, A.B., Morris, N.J., Gale, A.S., Rosen, B.R., 1995. Late Cretaceous (Maastrichtian) echinoid-mollusc-coral assemblages and palaeoenvironments from a Tethyan carbonate platform succession, northern Oman Mountains. Palaeogeogr. Palaeoclimatol. Palaeoecol. 119, 155-168. 
Tavares, Y.A.G., Borzone, C.A., 1998. General features of population dynamics of the sand dollar Mellita quinquiesperforata (Leske, 1778) in southern Brazilian sandy beaches. In: Mooi, R., Telford, M. (Eds.), Echinoderms: San Francisco. Proc. 9th Int. Echinoderm Conf., San Francisco, CA, 5-9 Aug. 1996. A.A. Balkema, Rotterdam, pp. 837-642.

Thum, A.B., Allen, J.C., 1975. Distribution and abundance of the lamp urchin Echinolampas crassa (BELL) 1880 in False Bay, Cape. Trans. R. Soc. S. Afr. 41, 359-373.

Timko, P.L., 1976. Sand dollars as suspension-feeders: a new description of feeding in Dendraster excentricus. Biol. Bull. 151, 247-259.

Wagner, C.D., 1974. Fossil and Recent sand dollar echinoids of Alaska. J. Paleontol. 48, 105-123.

Zavodnik, D., 1988. Astropectinidae (Echinodermata: Asteroidea) of the Adriatic Sea. In: Burke, R.D., Mladenov, P.V., Lambert, P., Parsley, R.L. (Eds.), Echinoderm Biology. Proc. 6th Int. Echinoderm Conf., Victoria, 23-27 Aug. 1987. A.A. Balkema, Rotterdam, pp. 363-368. 